\title{
CELA1 Gene
}

National Cancer Institute

\section{Source}

National Cancer Institute. CELA1 Gene. NCI Thesaurus. Code C115176.

This gene is involved in protein hydrolysis. 